\title{
MAKING IMMIGRANT RIGHTS REAL: NONPROFITS AND THE POLITICS OF INTEGRATION IN SAN FRANCISCO
}

\section{Tornando reais os direitos dos imigrantes: organizações não lucrativas e a política de integração em São Francisco}

DE GRAAUW, Els. Cornell University Press, 2016, 248 p.

O livro de Els de Graauw apresenta como organizações não-lucrativas que atendem imigrantes conseguem influenciar políticas locais de integração para essa população na cidade de São Francisco (Califórnia) nos Estados Unidos da América. A reflexão dessa obra reconhece o papel dessas organizações como tradutoras dos interesses dos imigrantes com possibilidade de negociar e influenciar governos. Dessa forma, essas organizações auxiliam os imigrantes no processo de integração local e advogam por direitos da população imigrante, principalmente a indocumentada, que nem sempre atua politicamente. A autora argumenta que as organizações desenvolvem relações de confiança com os imigrantes, conseguindo influenciar em políticas de integração no nível local, que é onde ocorre a integração de imigrantes.

Ainda que se aplique ao caso dos EUA, esse trabalho pode motivar estudos sobre a atuação política de organizações da sociedade civil tanto no nível local (munícipio) como no estadual e federal no Brasil mesmo que a relação entre os entes federados seja diferente nos EUA e no Brasil. De Graauw mostra que, assim como no Brasil, não existe um programa federal de integração local para imigrantes nos EUA. Assim, as organizações da sociedade civil são as principais responsáveis por realizar advocacy (considerando os interesses da população imigrante), passar informações para os imigrantes (incluindo sobre como acessar serviços públicos) e apoiar em sua integração, incluindo por meio de parcerias com outras organizações. Isso também é o que acontece no caso brasileiro. No Brasil, há uma literatura importante que destaca o papel

Doutoranda em Ciência Política pela Universidade de São Paulo e Visiting Scholar no Jacobs Center for Productive Youth Development. São Paulo, Brasil. E-mail: patnabuco@usp.br. Orcid: 0000-0003-2611-2513. 
de organizações da sociedade civil no acolhimento e prestação de serviços a imigrantes e refugiados. Dornelas (2018) discute desafios para o "acolhimento" e integração social de imigrantes que deve ser baseado no contato humano, em princípios da fé e da escuta. Um deles, seria a atuação de Mediação social entre migrantes e as sociedades em que eles estão inseridos. O mesmo foco analítico está presente nos trabalhos de Banacu et alii (2017) e de Cruz Stefanelli e Bastos (2016) sobre a atuação da Missão Paz em São Paulo, de Mialhe e Malheiro (2016) sobre a atuação das organizações não-governamentais e os refugiados no Brasil, de Costa (2011) sobre o acolhimento dos imigrantes haitianos pela Pastoral do Migrante em Manaus, de Borba (2016) sobre a atuação da sociedade civil na integração de refugiados no $A B C$, de Geremia (2016) sobre a acolhida de imigrantes e refugiados pela Igreja Católica no Brasil e de Sampaio (2008) sobre o atendimento de assistentes sociais parte da Rede Solidária de Migração e Refúgio aos refugiados no Brasil.

Santos (2003) apresenta a experiência da Caritas Arquidiocesana de São Paulo no atendimento a refugiados, reconhecendo que desde 1997 a Arquidiocese de São Paulo já começava a acolher refugiados. O trabalho ainda reconhece as parcerias da Caritas com outras organizações em São Paulo para acolher os refugiados e também a parceria com o Instituto Migrações e Direitos Humanos (IMDH) em Brasília. Ainda que Santos (2003) mencione brevemente a atuação de organizações da sociedade civil na discussão e implementação da Lei 9474/1997 (Lei do Refúgio) e no Plano Nacional de Direitos Humanos, o foco de seu trabalho é mais no acolhimento do dia-a-dia e não na atuação política em rede dessas organizações, incluindo suas estratégias de advocacy.

O que todos esses trabalhos têm em comum é discutir a atuação de determinadas organizações da sociedade civil (grande parte deles ligadas à Igreja Católica), algumas vezes em parceria, para garantir o acolhimento do imigrante em temas como acesso à documentação, acomodação, alimentação, cursos de português e trabalho. Esses são temas muito importantes que devem ser analisados. Contudo, não há grandes estudos, a exemplo da obra aqui resenhada, que analisam as estratégias políticas e dessas organizações que têm uma atuação de advocacy tanto no nível local quanto no nacional em favor dos imigrantes e refugiados.

Um trabalho que tocaria nesse ponto político é o capítulo de Botega e Ruano (2015) que analisa a atuação de diferentes atores na Conferência sobre Migração e refúgio no Distrito Federal e sua contribuição para a política migratória, além da aproximação entre os atores da sociedade civil e do governo. Essa forma de atuação política não é o modelo apresentado na obra resenhada e que poderia ser utilizado como base para análises envolvendo a atuação política dos atores da sociedade civil no Brasil. Isso não quer dizer 
que a atuação política de organizações da sociedade civil que trabalham com imigrantes seja trivial ou fácil de acontecer.

Els de Graauw apresenta alguns desafios para a atuação política dessas organizações. O primeiro é que, diferentemente do Brasil, as organizações nos EUA são proibidas por lei de realizarem lobby no poder legislativo. Elas também não podem apoiar nem financiar candidatos específicos. Já o segundo desafio, que também existe no Brasil, é que muitas organizações dependem financeiramente de fundos públicos. Dessa forma, essas sofreriam maiores constrangimentos para criticarem governos e atuarem politicamente do que organizações que não dependem desse financiamento. Apesar disso, a autora mostra que as organizações, utilizando diferentes estratégias como a) advocacy administrativo (com as prefeituras); b) colaborações entre setores e organizações e c) enquadramento estratégico de temas, conseguiram aprovar, no nível local, diferentes políticas que contribuíram para melhorar a vida dos imigrantes.

Na obra de Els de Graauw são analisados três estudos de caso na cidade de São Francisco: a aprovação de uma política que garante documentos públicos no idioma de imigrantes, a aprovação de um salário mínimo no nível local e a aprovação de um documento de identidade municipal. Em todos esses casos, as organizações tiveram que atuar criativamente construindo alianças com figuras do poder executivo, colaborando com organizações como sindicatos e deixando claro que essas políticas eram destinadas para melhorar a vida da população de São Francisco como um todo e não de imigrantes, principalmente de indocumentados. Os casos, estudados a fundo, mostram quais movimentações foram necessárias e os problemas e barreiras enfrentados. Esse tipo de análise seria interessante de ser replicado no Brasil, principalmente considerando a atuação política de diferentes organizações para aprovar a Lei de Migrações e a atuação da Pastoral do Migrante e de outras organizações junto às autoridades locais para facilitar procedimentos e acesso a direitos para a população imigrante.

O livro é indicado para todos os interessados no tema da imigração, mas sobretudo para trabalhadores das organizações que atuam com imigrantes que podem aprender com as experiências de São Francisco.

\section{Referências bibliográficas}

BANACU, Simona et alii. Missão Paz: Uma discussão sobre inclusão social e o migrante. Revista ENIAC Pesquisa, Guarulhos (SP), v. 6, n. 1, jan.- jun. 2017.

BORBA, Janine Hadassa Oliveira Marques de. A atuação das instituições da sociedade civil no processo de integração local de refugiados no ABC. In: BAGGIO, Fábio; PARISE, Paolo; SANCHEZ, Wagner Lopes (coords.). Mobilidade humana e identidades religiosas. São Paulo: Paulus, 2016, p. 201-218. 
COSTA, Gelmino A. Imigração Haitiana em Manaus: Presença da Pastoral do Migrante. Revista Travessia, n. 68, p. 83-88, Janeiro-Junho 2011.

CRUZ STEFANELLI, Mércia Maria; BASTOS, Sênia. Missão Paz: Lugar de Hospitalidade e Acolhimento aos I-Migrantes na Cidade de São Paulo, SP. Rosa dos Ventos, v. 8, n. 3, 2016.

DORNELAS, Sidnei Marco Dornelas. Migrações Contemporâneas: Desafios para a Acolhida e a Integração Social a partir da Pastoral do Migrante. Revista Travessia, n. 82, p. 121-143, Janeiro-Abril 2018.

GEREMIA, Mário. A acolhida dos migrantes e refugiados pela Igreja Católica no Brasil. In: BAGGIO, Fábio; PARISE, Paolo; SANCHEZ, Wagner Lopes (coords.). Mobilidade humana e identidades religiosas. São Paulo: Paulus, 2016, p. 173190.

MIALHE, Jorge Luis; MALHEIRO, Karina Caetano. Os Refugiados no Brasil e as Organizações Não-Governamentais. Revista de Direitos Humanos em Perspectiva, Brasília, v. 2, n. 1, p. 37-55, Jan/Jun. 2016.

RUANO, Elizabeth; BOTEGA, Tuíla. Atores e Saberes na Conferência sobre Migração e Refúgio no Distrito Federal. In: VASCONCELOS, Ana Maria Nogales; BOTEGA, Tuíla (orgs.). Política Migratória e o Paradoxo da Globalização. Porto Alegre/Brasília: EDIPUCRS/CSEM, 2015, p. 105-134.

SAMPAIO, Cyntia de Albuquerque. Serviço Social e Direitos Humanos: uma análise sobre os refugiados no Brasil. REMHU, Revista Interdisciplinar da Mobilidade Humana, v. 16, n. 31, p. 440-448, 2008.

SANTOS, José Paulo de Faria. Os Refugiados e a Sociedade Civil: A experiência da Cáritas Arquidiocesana de São Paulo. In: MILESI, Rosita (org.). Refugiados: realidade e perspectivas. Brasília: CSEM/IMDH; Edições Loyola, 2003, p. 135154. 